\title{
Glaciological studies at Siple Station (Antarctica): potential ice-core paleoclimatic record
}

\author{
E. Mosley-Thompson, J. Dai, L. G. Thompson, \\ Byrd Polar Research Center, The Ohio State University, Columbus, Ohio 43210-1308, U.S.A. \\ P. M. GROOTES, \\ Quaternary Isotope Laboratory, University of Washington, Seattle, Washington 98195, U.S.A. \\ James K. Arbogast and J. F. Paskievitch \\ Byrd Polar Research Center, The Ohio State University, Columbus, Ohio 43210-1308, U.S.A.
}

\begin{abstract}
The quality and utility of the records of oxygen-isotopic abundances, dust concentrations and anionic concentrations preserved in the ice at Siple Station $\left(75^{\circ} 55^{\prime} \mathrm{S}, 84^{\circ} 15^{\prime} \mathrm{W}\right)$ are assessed from four shallow $(20 \mathrm{~m})$ cores. The combination of high accumulation $\left(0.56 \mathrm{~m} \mathrm{a}^{-1}\right.$ w.e. $)$ and low mean annual temperature $\left(-24^{\circ} \mathrm{C}\right)$ preserves the prominent seasonal variations in $\delta^{18} \mathrm{O}$ which are very spatially coherent. Sulfate concentrations vary seasonally and, in conjunction with $\delta^{18} \mathrm{O}$, will allow accurate dating of deeper cores from Siple Station. The concentrations of insoluble dust are the lowest measured in Antarctica, making Siple Station an excellent location to examine large increases in atmospheric tubidity.

The seasonal variations and annual fluxes of the anions are examined for the last two decades (AD 1966-85) with regard to probable sources. An unusually high sulfate flux in 1976 may reflect the February 1975 eruption of Mount Ngauruhoe, New Zealand. No annual signal in nitrate concentration is confirmed and no unusually high nitrate fluxes support the suggestion of nitrate production by large solar flares. However, nitrate flux is higher for the latter half of the 1970s and early 1980s, possibly reflecting the recent loss of stratospheric ozone.

Finally, comparison of the $\delta^{18} \mathrm{O}$ record with available surface-temperature data (AD 1957-85) reveals that multi-year trends along the western coast of the Antarctic Peninsula are recorded at Siple. More importantly, comparison with areally weighted temperature reconstructions suggests that the $\delta^{18} \mathrm{O}$ record may reflect larger-scale, persistent trends in the high southern latitudes. The strong spatial coherence of the preserved records, the potential for accurate dating, and possible relevance to largerscale processes make Siple Station an excellent site for paleoenvironmental reconstruction from ice cores.
\end{abstract}

\section{INTRODUCTION}

Current emphasis upon the comprehensive investigation of the global environmental system (National Research Council, 1986, p. 1-6, 1988) has drawn attention to ice sheets and ice caps which continuously record and preserve the physical and chemical character of the atmosphere. The extraction of an environmental history from an ice core requires evaluation of both the temporal quality and spatial variability of the record which limits its utility as an environmental proxy. The gases trapped in ice bubbles at Siple Station have provided a unique, highresolution record of atmospheric chemistry (Stauffer and Oeschger, 1985; Friedli and others, 1986). Here we explore the potential of the $\delta^{18} \mathrm{O}$, particulate, and chemical records anticipated from a $302 \mathrm{~m}$ core for reconstruction of paleoenvironmental conditions in the high southern latitudes.

In support of deeper cores (302 and $132 \mathrm{~m}$ ) drilled at Siple Station, Antarctica $\left(75^{\circ} 55^{\prime} \mathrm{S}, 84^{\circ} 15^{\prime} \mathrm{W}, 1054 \mathrm{~m}\right.$ a.s.l.; Fig. 1), during the 1985-86 austral summer (Mosley-Thompson and others, 1986), eight additional shallow cores $(20 \mathrm{~m})$ were collected and samples were taken from three pits. The $20 \mathrm{~m}$ core records encompass 20 years (AD 1966-85) and in combination with pit studies represent a sampling area of several $\mathrm{km}^{2}$. These have been used to examine the potential for accurate dating, to obtain basic glaciological information such as annual accumulation rate and density variations with depth, to examine the spatial reproducibility of the preserved 


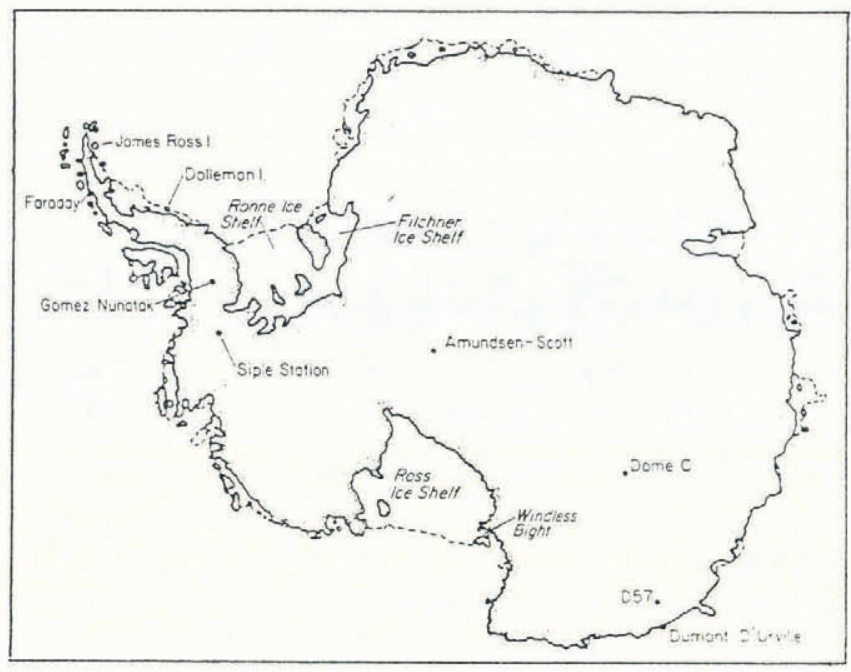

Fig. 1. Antarctic sites for results cited in the text and in Table 1 . records, and to assess their relevance to larger-scale processes.

Soluble impurities in Antarctic snow and ice provide unique information about both present and past atmospheric chemical composition. Siple Station, located near the base of the Antarctic Peninsula (Fig. 1), offers the opportunity to study precipitation chemistry at a site intermediate between the coastal areas, where sea-salt aerosol has a strong influence and the interior where secondary aerosol tends to be dominant. For the purposes of this paper, the Antarctic seasons are loosely defined as: summer, December-February; winter, March-September; and spring, October-November.

\section{SAMPLE ACQUISITION, PREPARATION AND} ANALYSES

Drilling and pit sampling were conducted $2 \mathrm{~km}$ upwind of

Table 1. Chloride, nitrate and sulfate in Antarctic snow

\begin{tabular}{|c|c|c|c|c|}
\hline $\begin{array}{l}\text { Location (Fig. 1) } \\
\text { (Reference) }\end{array}$ & Years & $\begin{array}{l}\text { Number of } \\
\text { samples }\end{array}$ & $\mathrm{Cl}^{-}$ & $\mathrm{NO}_{3}^{-}$ \\
\hline
\end{tabular}

average in $\mu \mathrm{eq} / \mathrm{l} \quad \mathrm{mm}$ w.e

\begin{tabular}{lcccccc}
$\begin{array}{l}\text { Siple } \\
\text { (this work) }\end{array}$ & $1965-85$ & 284 & 2.48 & 0.45 & 0.77 & 540 \\
$\begin{array}{l}\text { Siple } \\
\text { (Herron, 1982) }\end{array}$ & - & - & $\sim 2.0$ & $\sim 0.5$ & $\sim 0.7$ & $\sim 400$ \\
$\begin{array}{l}\text { Gomez Nunatak } \\
\text { (Mulvaney and Peel, 1988) }\end{array}$ & $1942-80$ & 612 & 2.3 & $\sim 0.4$ & $\sim 0.8$ & 880 \\
$\begin{array}{l}\text { Dolleman Island } \\
\text { (Mulvaney and Peel, 1988) }\end{array}$ & $1973-85$ & 143 & 11.8 & $\sim 0.4$ & $\sim 5.0$ & 540 \\
$\begin{array}{l}\text { James Ross Island } \\
\text { (Aristarain and others, 1982) }\end{array}$ & $1964-78$ & 312 & $>10.0$ & 0.4 & 1.8 & 490 \\
$\begin{array}{l}\text { South Pole } \\
\text { (Legrand and Delmas, 1984) }\end{array}$ & $1959-69$ & 100 & 1.25 & 1.44 & 1.50 & 85 \\
$\begin{array}{l}\text { Dome C } \\
\text { (Delmas and others, 1982) }\end{array}$ & $1960-78$ & - & - & $\sim 0.23$ & $\sim 1.9$ & 34 \\
$\begin{array}{l}\text { Site D57 } \\
\text { (Zanolini and others, 1985) }\end{array}$ & pre-1900 & - & - & 0.7 & 0.5 & 30 \\
$\begin{array}{l}\text { Ross Ice Shelf (Windless Bight) } \\
\text { (Zeller and others, 1986) }\end{array}$ & $1971-86$ & 90 & - & $\sim 2.0$ & - & 200 \\
\hline
\end{tabular}

Estimated from diagrams.

- Information not available. 
the station to reduce the potential of contamination. All cores and pit samples were stored below $-20^{\circ} \mathrm{C}$ until just prior to laboratory analysis. Samples were initially prepared in a cold working room $\left(-15^{\circ} \mathrm{C}\right)$ where a band saw was used to cut the samples directly from the core. A minimum of $20 \mathrm{~mm}$ of material was removed from all sides to obtain fresh samples of the desired size which were placed in pre-cleaned containers. With the exception of the $\delta^{18} \mathrm{O}$ samples, further cleaning, melting and analysis were conducted in a Class-100 clean-room laboratory.

Millipore Milli-Qultra-pure, deionized, filtered water was used for cleaning of all samples and containers and for preparing eluants and standards. The concentration of insoluble microparticles with diameters $\geqslant 0.63 \mu \mathrm{m} \mathrm{ml}^{-1}$ (MPC) were measured by a Model TA II Coulter counter, using a procedure described elsewhere (Thompson, 1977). The electrical conductivity (EC) of liquid samples was measured using a Beckman RC-20 conductivity bridge. The $\delta^{18} \mathrm{O}$ measurements were made with a stable-isotope mass spectrometer at the Quaternary Isotope Laboratory of the University of Washington.

The anion concentrations were determined with a Dionex Model 2010i ion chromatograph equipped with an AS4A anion separator column and a micro-membrane suppressor column. Carbonate/bicarbonate (0.0012/ $0.00038 \mathrm{~mol} \mathrm{l}^{-1}$ ) eluant was used, along with $0.1 \mathrm{moll}^{-1} \mathrm{H}_{2} \mathrm{SO}_{4}$ as regenerant for the suppressor. Analytical precision and sensitivity were significantly improved over the method previously reported by Legrand and others (1984) which has been recently upgraded by Saigne and others (1987). The use of a relatively large injection loop $(0.64 \mathrm{ml})$ eliminated the need for a concentrator column (Arbogast, 1987), while preserving the desired detection limits (c. $\sim 1 \mathrm{ppb}$ for $\mathrm{Cl}^{-}$, $\mathrm{NO}_{3}^{-}$, and $\mathrm{SO}_{4}{ }^{2-}$ ). Working standards were prepared daily from stock solutions and procedural blanks were included in each analytical session for every step in sample handling, beginning with the cutting by band saw. Only minor amounts $(<5 \mathrm{ppb})$ of $\mathrm{Cl}^{-}$were observed in a few cases. The time required for each analysis (injection) is approximately $10 \mathrm{~min}$. The ionic concentrations are comparable to previously published values (Table 1), suggesting that the contamination control procedures employed are effective.

\section{SHALLOW-CORE RESULTS: (AD 1966-85)}

\section{Oxygen-isotope ratios $\left(\delta^{18} \mathrm{O}\right)$}

Figure 2 illustrates $\delta^{18} \mathrm{O}$ for three $20 \mathrm{~m}$ cores (cores 2, 6 and 8 ) and the upper $18 \mathrm{~m}$ of core $\mathrm{A}$ which was drilled in a $2 \mathrm{~m}$ trench. The depth in firn was converted to waterequivalent depth using the depth-density relationship derived from density measurements in pits and on cores. Figure 2 clearly demonstrates that $\delta^{18} \mathrm{O}$ exhibits a

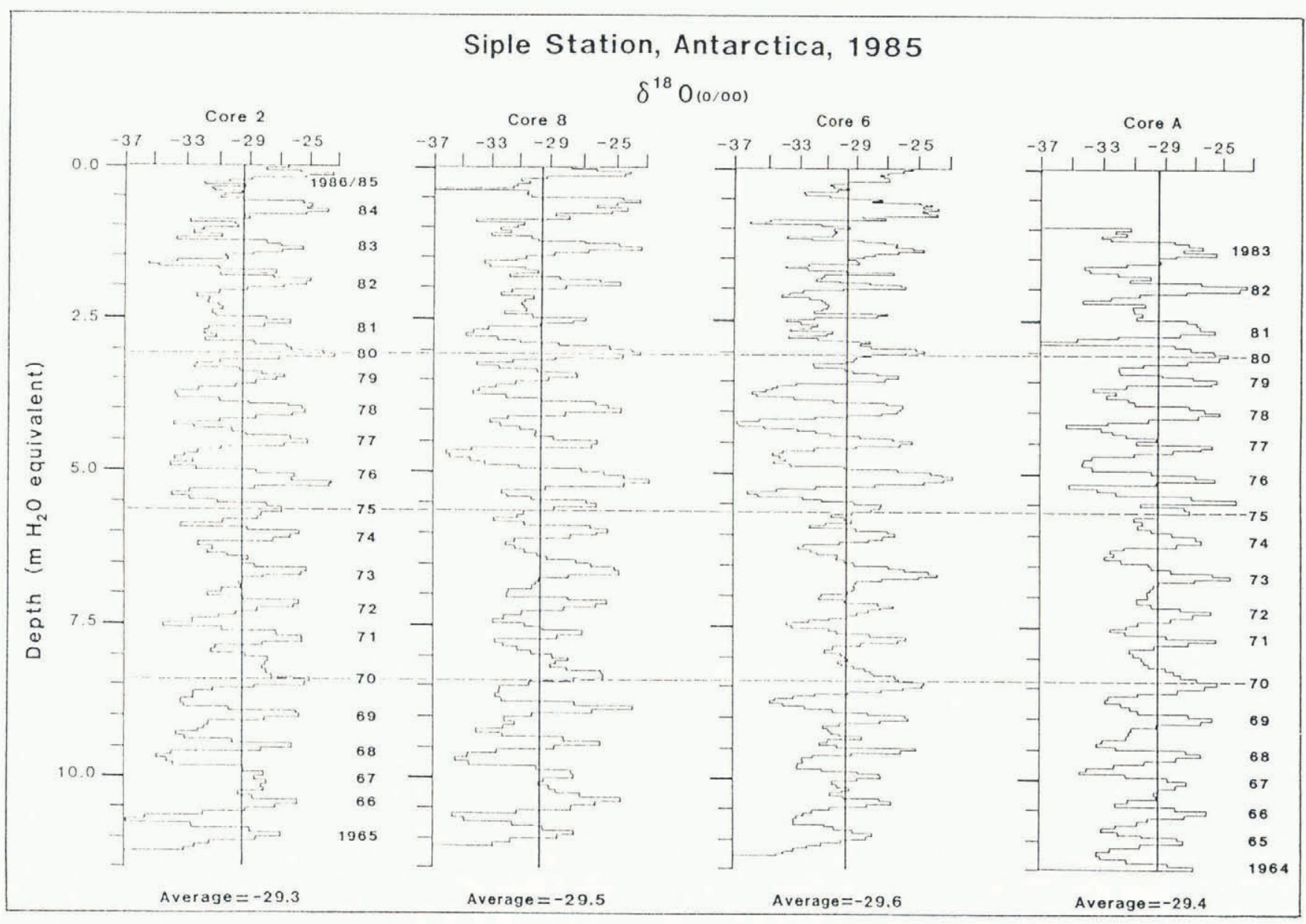

Fig. 2. Oxygen-isotope $\left(\delta^{18} \mathrm{O}\right)$ ratios for three $20 \mathrm{~cm}$ cores (2,6 and 8) and the upper $18 \mathrm{~m}$ of core $A$ illustrate the spatial reproducibility of the record. The firn depths were converted to water-equivalent depths using a depth-density relationship derived empirically from pit- and core-density data. 
Table 2. $\delta^{18} \mathrm{O}$ results from four $20 \mathrm{~m}$ cores (AD 1966-85). Pearson correlation coefficients and significance levels

$\begin{array}{lcccc}\text { (A) Annual averages } & & & & \\ \text { Core } & 2 & 6 & 8 & A \\ 2 & 1 & 0.644 & 0.734 & 0.403 \\ & & (99.0) & (99.0) & (90.0) \\ 6 & & 1 & 0.742 & 0.432 \\ & & & (99.9) & (93.0) \\ 8 & & & 1 & 0.537 \\ & & & & (95.0)\end{array}$

$\begin{array}{lcccc}\text { (B) Winter averages } & & & & \\ \text { Core } & 2 & 6 & 8 & A \\ 2 & 1 & 0.594 & 0.870 & 0.552 \\ & & (99.0) & (99.9) & (95.0) \\ 6 & & 1 & 0.567 & 0.747 \\ & & & (99.0) & (99.0) \\ 8 & & & 1 & 0.529 \\ & & & & (95.0)\end{array}$

(C) Summer averages

\begin{tabular}{lcccc} 
Core & 2 & 6 & 8 & $A$ \\
2 & 1 & $\begin{array}{c}0.600 \\
(99.0)\end{array}$ & $\begin{array}{c}0.680 \\
(99.0)\end{array}$ & NS \\
6 & & 1 & 0.467 & NS \\
8 & & & $(95.0)$ & \\
& & & 1 & NS \\
\hline
\end{tabular}

NS: Not significant at any acceptable level $(<90 \%)$.

$(\sigma)$ : Significance level.

Number of observations: 20 for cores 2, 6 and 8, and 18 for core A.

consistent seasonal signal as previously demonstrated by Swiss analyses of a 1983 core. Their work on a single core did not allow investigation of the spatial reproducibility of the $\delta^{18} \mathrm{O}$ records. Near the surface, sub-annual events (e.g. 1983-82 and 1982-81) are preserved from one site to another; however, below $3 \mathrm{~m}$, these events are smoothed. Signal reproducibility is evident.

A statistical examination (Table 2) reveals significant $(\sigma \geqslant 95 \%)$ correlations among all four cores for winter averages and among cores 2, 6 and 8 for both annual and summer averages. The seasonal averages consist of all values in a given year which are above or below the 20 year mean for the respective core. The lower correlations for summer probably reflect the increased control of topography upon the surface-energy balance during periods of little or zero accumulation. Core A is correlated least with the other cores and there are no obvious differences in handling or analysis. However, core A contains only 18 years which means there are two less degrees of freedom which lowers the significance level. Excellent correlations among cores 2,6 and $8(\sigma \geqslant 95 \%)$ for both annual and intra-annual periods suggest that $\delta^{18} \mathrm{O}$ trends in deeper cores should be representative of the Siple Station area.

\section{Insoluble microparticle concentrations (MPC)}

Figure 3 presents the MPC, $\delta^{18} \mathrm{O}$ and EC profiles for two 


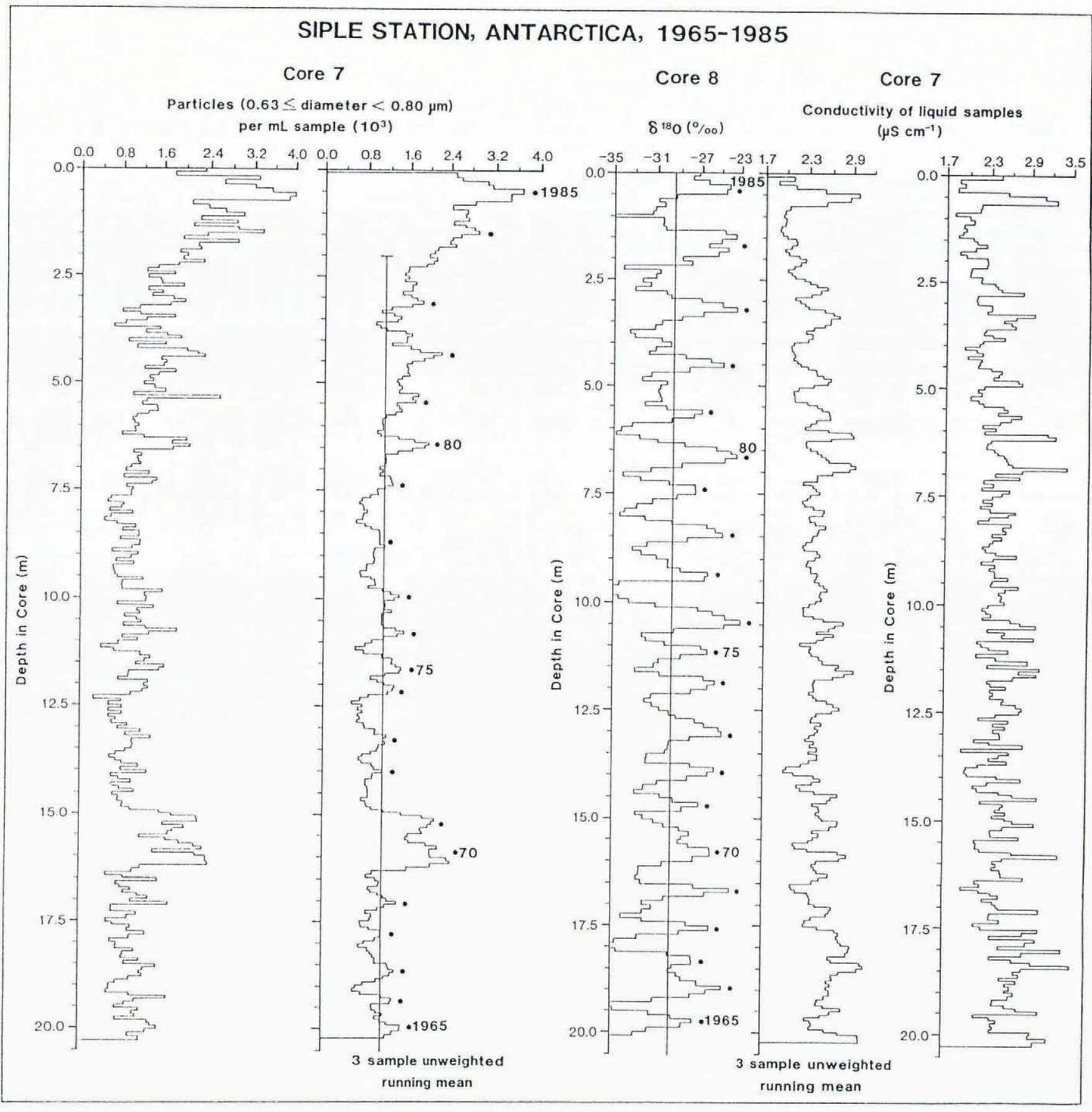

Fig. 3. Microparticle concentrations $(0.63 \geqslant$ diameter $\geqslant 0.80 \mu \mathrm{m})$ and electrical conductivity of liquid samples in core 7 are illustrated along with their respective three-sample unweighted running mean. The time-scale based on the core $8 \delta^{18} \mathrm{O}$ record is illustrated.

$20 \mathrm{~m}$ cores (cores 7 and 8 ). The MPC and EC profiles have been smoothed with a three-sample unweighted running mean. Particulate concentrations are the lowest measured in Antarctica (Thompson and Mosley-Thompson, 1982) which necessitated using a sub-coring device to remove samples from the interior of the core. Although particulate concentrations vary seasonally, the low concentrations often approach background levels. Smoothing enhances the seasonal signal (Fig. 3), but insoluble particulates do not provide a reliable means for dating deeper cores. The very low concentrations attest to the lack of a significant contribution from local sources. In fact, with such low background concentrations, the Siple Station cores should provide an excellent record of major dust events reaching the high southern latitudes.

\section{Electrical conductivity (EC)}

EC does not exhibit a distinct seasonal signal (Fig. 3) and therefore is not reliable for dating. This is in sharp contrast to direct current (d.c.) conductivity measured on the 1983 core which provided a well-defined seasonal signal used to date the upper $144 \mathrm{~m}$ (Schwander, 1984, p. 66-71). Anion analyses (below) show that $\mathrm{SO}_{4}{ }^{2-}$ concentrations reach a maximum during summer while $\mathrm{Cl}^{-}$concentrations generally peak in winter. Both anions and their counter 
ions are soluble and can contribute to EC. The d.c. measurement, which reflects the total $\mathrm{H}^{+}$concentration, is more closely associated with $\mathrm{SO}_{4}{ }^{2-}$ concentrations.

\section{Anionic chemistry}

Core 6 was devoted to $\delta^{18} \mathrm{O}$ and anion analyses. 284 samples of approximately $70 \mathrm{~mm}$ length were cut from the $20 \mathrm{~m}$ core providing a range of 1-22 samples per year. The flux (mass/area) of each anion was calculated by multiplying the concentration by the sample length (in water equivalent). The annual flux for each anion is the sum of the fluxes for each year. Negative values of excess sulfate (discussed below) were excluded from annual flux calculations.

Concentrations of major soluble chemical species (Table 1) have been measured by other researchers in snow and ice samples from various areas in Antarctica (Fig. 1). Our results are in excellent agreement with previously reported analyses of Siple Station samples (Herron, 1982).

\section{Chloride}

Legrand and Delmas (1984) demonstrated that chloride in polar snow results mainly from the deposition of sea-salt aerosol (as $\mathrm{NaCl}$ ), particularly in coastal areas. On Dolleman Island in the Antarctic Peninsula, sea-salt chloride comprises $\approx 95 \%$ of total chloride (Mulvaney and Peel, 1988). Chloride levels at Siple Station (Table 1) fall between the high levels at coastal sites (e.g. James Ross Island and Dolleman Island) and the low levels at continental sites (e.g. South Pole). Legrand and Delmas estimated sea-salt chloride to be $50-60 \%$ of total chloride at the South Pole. Consequently, sea-salt chloride at Siple Station is probably a dominant part of total chloride, between 60 and $95 \%$.

Figure 4 illustrates that chloride exhibits an annual cycle with highest concentrations generally associated with winter precipitation. However, during winter and perhaps early spring multiple-concentration maxima are common. The multiple-concentration peaks are evident in the snowpit samples (not illustrated). Mulvaney and Peel (1988) reported a clear annual peak in chloride concentration in snow on Dolleman Island, corresponding to the late summer/autumn period, which they attributed to minimum sea-ice extent in the Weddell Sea. At another coastal site close to the Weddell Sea, Wagenbach and others (1988) reported a concentration maximum of sea-salt aerosol in autumn. Located further from the Weddell Sea, Siple Station is unlikely to receive the abundance of summer/autumn sea-salt aerosol that produces the annual chloride peak on Dolleman Island. The much lower chloride concentrations at Siple Station (Table 1) supported this. The different season for maximum chloride concentrations also suggests that seasonal variations in sea-salt aerosol at Siple Station are not closely associated with sea-ice conditions in the Weddell Sea region.

\section{Sulfate}

It is well established that sulfate concentration in

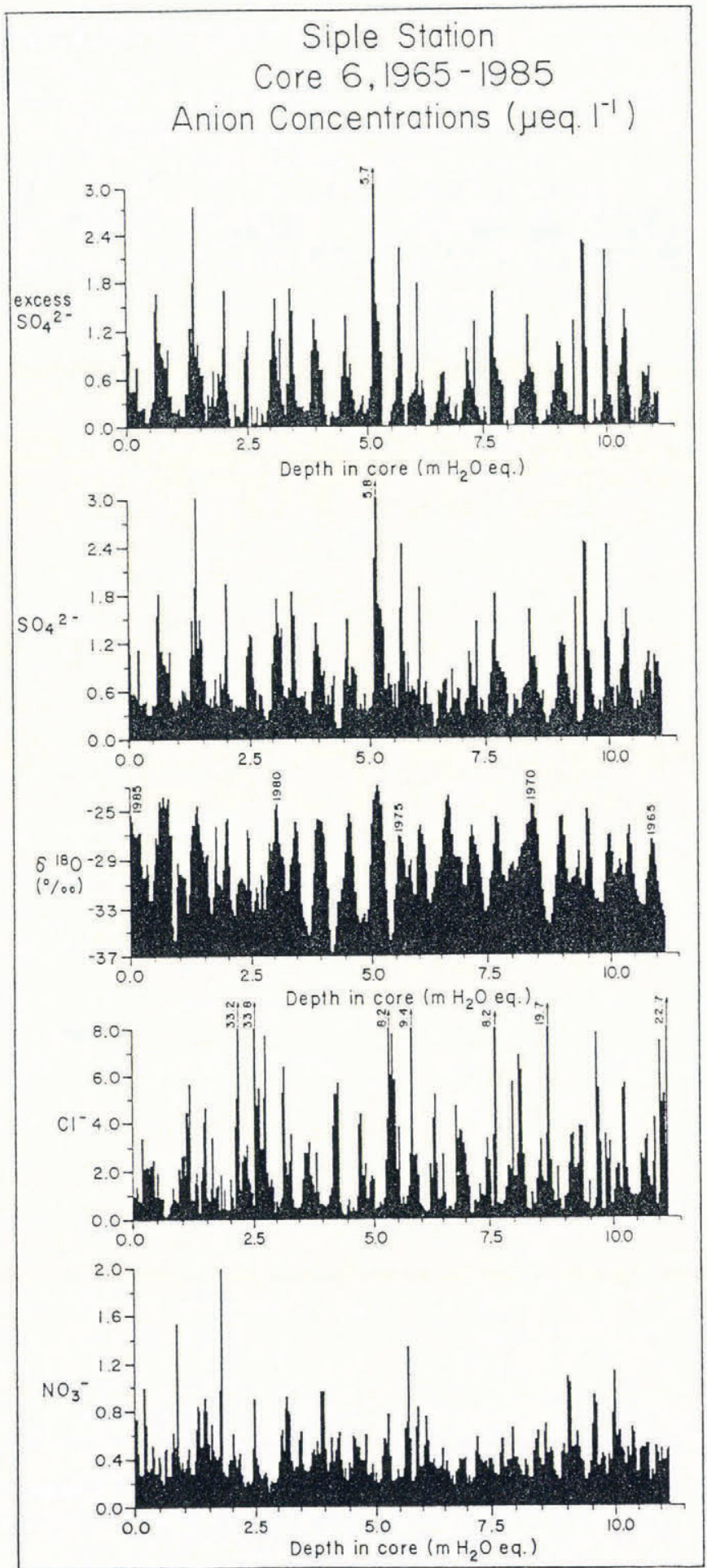

Fig. 4. Concentrations ( $\mu e q 1^{-1}$ ) of chloride, sulfate, excess sulfate, and nitrate from core 6 are illustrated along with $\delta^{18} \mathrm{O}$ used to date the core. Excess sulfate is estimated according to Equation (1). Off-scale concentrations are provided.

Antarctic snow varies seasonally. Annual summer maxima and winter minima have been observed on the Antarctic Peninsula (Aristarain and others, 1982; Mulvaney and Peel, 1988), in East Antarctica (Legrand and Delmas, 1985) and at the South Pole (Legrand and Delmas, 1984). Measuring the sulfate concentration in ground-level aerosols, Wagenbach and others (1988) found a prominent seasonal cycle similar to that in snow. The unsmoothed sulfate profile for the $20 \mathrm{~m}$ firn core exhibits 


\section{Siple Station, 1965-1985} Annual Anion Fluxes, ( $\mu \mathrm{g} \mathrm{cm}^{-2} \mathrm{a}^{-1}$ )
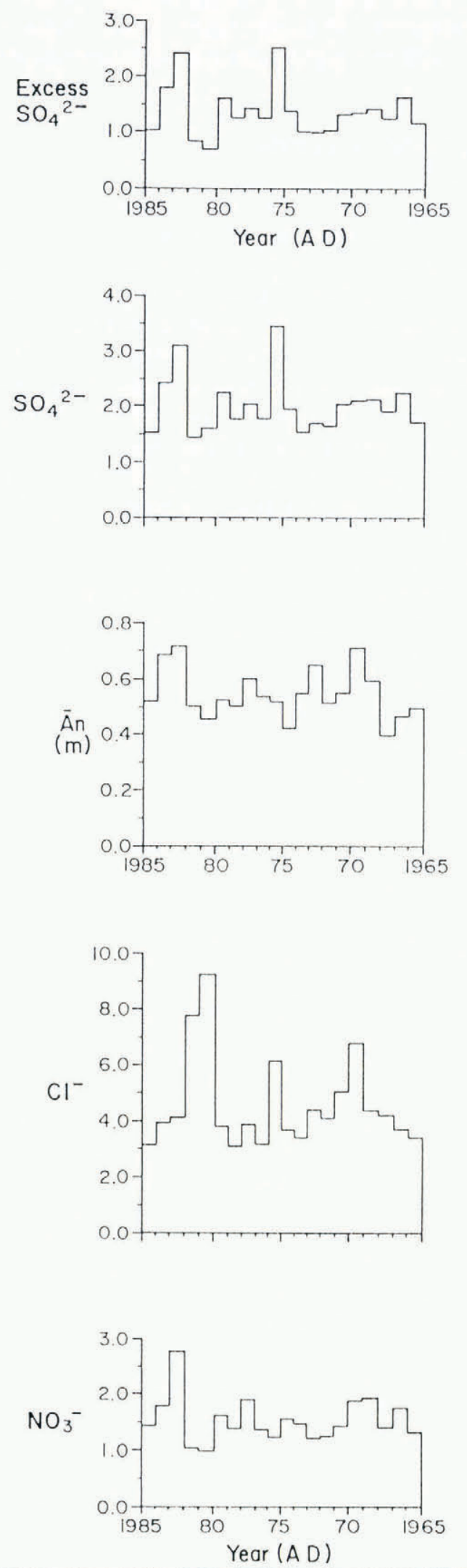

Fig. 5. Annual fluxes of chloride, sulfate, excess sulfate (excluding negative values), and nitrate, 1966-85, are illustrated along with annual net accumulation from core 6 . fairly regular annual cycles (Fig. 4). Of the three anions $\left(\mathrm{Cl}^{-}, \mathrm{SO}_{4}{ }^{2-}\right.$ and $\left.\mathrm{NO}_{3}^{-}\right)$, sulfate exhibits the best annual signal and appears to be a useful dating tool in this area.

Excess sulfate (sulfate contributions not from sea salt), has been calculated according to Equation (1) where $R$ $(0.103)$ is the ratio of sulfate/chloride ( $\mu$ equivalent $\mathrm{l}^{-1}$ ) in bulk sea water. It would be more appropriate to use sodium concentrations instead of chloride because nonsea-salt chloride may be present. However, sodium measurements are unavailable and thus Equation (1) is used for calculating excess sulfate. The error introduced by using total chloride in Equation (1) is estimated to be no more than $10 \%$ of excess sulfate.

$$
\left[\mathrm{SO}_{4}{ }^{2-}\right]_{\mathrm{ex}}=\left[\mathrm{SO}_{4}{ }^{2-}\right]_{\text {total }}-R\left[\mathrm{Cl}^{-}\right]
$$

Since chloride and total sulfate annual cycles are out of phase by $\sim 6$ months, the excess sulfate profile, which is essentially differentiation of sulfate and chloride, exhibits a more prominent annual signal than either chloride or sulfate. For example, Figure 4 clearly illustrates that the slightly ambiguous sulfate maxima in 1973 and 1974 are much more prominent in the excess sulfate profile. This profile also reveals that background (winter) excess sulfate concentration is generally close to zero. In 13 of the 284 samples, the calculated excess sulfate is substantially negative.

The annual sulfate-flux profile (Fig. 5) contains two peaks. The less prominent one in 1983 could reflect elevated annual accumulation. In contrast, the flux for 1976 is $3.5 \mu \mathrm{g} \mathrm{cm}^{-2}, 75 \%$ higher than the 20 year annual average of $2.0 \mu \mathrm{g} \mathrm{cm}^{-2}$. The sulfate flux for the previous year (1975) is also slightly elevated. A sudden increase in sulfate often indicates the presence of volcanic sulfate. Aristarain and others (1982) found two large acidity peaks in the James Ross Island core which were tentatively attributed to the February 1975 eruption of Mount Ngauruhoe $\left(37^{\circ} \mathrm{S}, 174^{\circ} \mathrm{E}\right.$ ) and to the 1963 eruption of Mount Agung $\left(08.3^{\circ} \mathrm{S}, 174^{\circ} \mathrm{E}\right)$. The large sulfate flux in 1976 at Siple Station may also reflect the Mount Ngauruhoe eruption. The Mount Agung eruption is not contained in the sulfate record presented here as the shallow cores do not extend to 1963-64.

This and previous work by others (e.g. Delmas and others, 1985) suggest that sulfate deposited from a small or moderate volcanic eruption is primarily restricted to a single year, and in many cases, to the summer maximum. Notice that the winter concentration minima before and after the 1976 sulfate peak (Fig. 4) are virtually unchanged. The extremely high concentrations or flux of sulfate are restricted to a very narrow depth interval (one or two samples, or $\approx 10 \mathrm{~cm}$ in w.e., corresponding to midsummer (December-January). The time lapse between the eruption (February 1975) and the maximum deposition ( $\sim$ December 1976 ) is much longer than required for the oxidation of the volcanic sulfur species $\left(\mathrm{SO}_{2}\right)$ to sulfate in the presence of light (McKeen and others, 1984). The presence of slightly elevated sulfate concentrations in 1975 summer snow suggests that at least part of the Mount Ngauruhoe volcanic gases reached this latitude, where sunlight is available only in summer. This implies that volcanic sulfur, although present in the atmosphere at this latitude, was not being removed as sulfate during the 
winter months. Indeed, the Siple Station data indicate virtually no sulfate deposition, except that from sea salt, in the austral night. Therefore, it appears that the rate of sulfate deposition reflects the availability of sunlight.

The major volcanic sulfur species $\left(\mathrm{SO}_{2}\right)$ and organosulfur species from marine biogenic activity, which are the precursors of excess sulfate (Legrand and Delmas, 1984), must be chemically transformed (oxidized) before surface deposition. Thus, in the overall process of marine and volcanic production, transportation, chemical transformation, and deposition of atmospheric sulfur in high southern latitudes, the rate-controlling factor appears to be photochemical oxidation. The subsequent deposition of sulfate is believed to be rapid because of efficient scavenging by precipitation of sulfate (as sulfuric acid) which serves as excellent condensation nuclei.

\section{Nitrate}

Nitrate concentrations vary less than those of chloride and sulfate. For the 284 samples, the ratio of standard deviation to the average is 0.49 for nitrate, compared to 1.4 for chloride and 0.71 for sulfate. Aristarain and others (1982) reported similar observations of nitrate concentrations with a relatively constant background level perturbed only by sporadic increases of unknown nature. The absence of extremely high concentrations, which are common for sulfate, suggests the absence of explosive sources such as volcanic eruptions. Antarctic nitrate concentrations are compared in Table 1. The average concentration at Siple Station (Herron, 1982, this work) compares well with those from three other Antarctic Peninsula sites (Gomez Nuntak, Dolleman Island and James Ross Island). Thus, nitrate concentrations do not vary greatly in this part of the continent.

Herron (1982) suggested the possibility of a constant nitrate flux over the Antarctic continent, in response to or resulting from an inversely proportional relationship between concentration and snow-accumulation rate. Data in Table 1 do not support this. The fluxes for eastern Antarctic sites (e.g. South Pole) and the Ross Ice Shelf are smaller than those for the Antarctic Peninsula sites.

An annual cycle in nitrate concentration similar to that of sulfate has been reported for Antarctica (Herron, 1982; Legrand and Delmas, 1984; Zeller and others, 1986). In the 20 years covered by this record, annual nitrate cycles are recognizable in some instances (e.g. 1974-82) and are ambiguous in others. In years with recognizable cycles, most nitrate peak concentrations occur just before the summer $\delta^{18} \mathrm{O}$ maxima, unlike the sulfate maximum in mid-summer. Actual measurements of coastal aerosols (Wagenbach and others, 1988) show that atmospheric nitrate concentration peaks in spring. At the South Pole, Legrand and Delmas (1984) found maximum annual nitrate concentrations shortly after summer. This discrepancy suggests that nitrate seasonality may not be consistent at all sites. The frequent high concentrations in spring reported here indicate that nitrate deposition may be related to springtime atmospheric chemistry and/or vertical movement of polar air masses.

Zeller and others (1986) cited large solar flares as potential sources of unusually high nitrate fluxes for 1972 and 1984 at a site on the Ross Ice Shelf. Neither the nitrate concentrations nor the flux profile from Siple Station contains such unusual peaks. Only the 1983 nitrate flux $\left(2.76 \mu \mathrm{g} \mathrm{cm}^{-2}\right)$ is substantially larger than the 20 year average $\left(1.52 \mu \mathrm{g} \mathrm{cm}^{-2}\right)$. This appears to result from the combination of unusually high annual accumulation $(0.70 \mathrm{~m})$ with the highest single nitrate concentration.

\section{NET ACGUMULATION}

The reconstruction of a representative accumulation history from longer cores requires that spatial variability in net accumulation $\left(A_{\mathrm{n}}\right)$ be low. Two independent data sets suggest strongly that $A_{\mathrm{n}}$ is nearly constant from site to site. Neftel and others (1985) reported a distinct melt layer in the summer of 1976 at $7 \mathrm{~m}$ below the 1983 surface. This same melt feature was present in eight of the ten cores drilled in 1985 and its depth varied from 10.46 to $10.63 \mathrm{~m}$ below the December 1985 surface. The depth of the 1976 feature, coupled with the depth-density relationship, indicates a 10 year average annual accumulation of $0.56 \mathrm{~m}$ (w.e.).

Using the $\delta^{18} \mathrm{O}$ seasonal variations, annual layer thicknesses in water equivalent were reconstructed using the depth-density relationship. The 20 year averages of $A_{\mathrm{n}}$ are $0.56 \mathrm{~m}$ w.e. for cores 2,6 and 8 , and $0.57 \mathrm{~m}$ w.e. for core A. Results of a linear correlation of $A_{\mathrm{n}}$ among the cores (Table 3 ) and the spatially consistent depth of the 1976 melt layer illustrate that accumulation has not varied substantially from one site to another over the last 20 years.

\section{ANION FLUXES}

Since the mid to late 1970s, there has been an increasing awareness of changes in the concentrations of atmospheric trace gases. In the South Polar regions, the most notable observation is the progressive decrease of ozone and the

Table 3. Pearson correlation coefficients and significance levels for an annual layer thickness in four shallow cores

\begin{tabular}{ccccc}
\hline Core & 2 & 6 & 8 & $A$ \\
\hline & & & & \\
2 & 1 & 0.728 & 0.865 & 0.686 \\
& & $(99.5 \%)$ & $(99.9 \%)$ & $(99.0 \%)$ \\
6 & & & 0.730 & 0.703 \\
& & & $(99.5 \%)$ & $(99.0 \%)$ \\
8 & & & 1 & 0.676 \\
& & & & $(95.0 \%)$ \\
& & & & \\
\end{tabular}

$(\sigma)$ : Significance level.

Number of observations: 20 for cores 2, 6 and 8; 18 for core A. 
resulting increase in the size of the Antarctic ozone "hole". While debates continue over the exact causes of the ozone decline, it is generally accepted that ozone destruction is the result of complicated chemical reactions involving atmospheric species of chlorine and nitrogen (Farman and others, 1985).

The exact effects which might be observed at ground level in response to changes in the stratosphere are undetermined. However, as the anions measured in this work may have stratospheric pathways, it is interesting to examine trends in their fluxes over the last two decades. The annual fluxes of chloride and sulfate are quite variable (Fig. 5). The 5 year average annual fluxes for chloride, sulfate, excess sulfate and nitrate, and the deviations from their respective 20 year means are given in Table 4 along with the annual accumulation (w.e.). The fluctuations in net annual accumulation are insufficient to cause large variations in the fluxes.

As discussed earlier, sea-salt aerosol accounts for most chloride in snow at Siple Station. A change in chloride flux at this location probably reflects a perturbation of conditions at ground level or in the lower troposphere and, therefore, is probably unrelated to stratospheric chemistry. Sulfate flux shows no particular pattern and the large flux for 1976-80 reflects partially the probable volcanic input of 1975-76. There is no evidence suggesting a direct involvement of sulfur species in the destruction of stratospheric ozone.

Nitrate flux is lowest for 1971-75. A substantial increase $(\sim 7-8 \%)$ is shown for each of the next two 5 year periods. Heath (1988) reported that during this decade, 1976-85, the loss of ozone in the South Polar region was progressing at a somewhat similar rate. However, an attempt to link the increase of nitrate flux to the ozone loss would have to explain the even higher flux of 1966-70. Clearly, a longer record is needed to examine the natural variability of nitrate flux and a better understanding of nitrate sources is essential.

\section{SURFACE TEMPERATURES AND THE $\delta^{18} \mathrm{O}$ RECORD}

Siple Station (1054 $\mathrm{m}$ a.s.1.) is located in an area where the complex near-surface wind regime of the Antarctic Peninsula region (Schwerdtfeger and Amaturo, 1979) and that of the high inland plateau converge. Hence, Siple Station may occupy a sensitive climatic setting ideal for isolating longer-term large-scale environmental changes affecting the entire region.

Although $\delta^{18} \mathrm{O}$ reflects other environmental factors in addition to condensation temperature, this record is interpreted strictly on the basis of temperature (more negative - cooler; less negative - warmer). Annual $\delta^{18} \mathrm{O}$ averages were possible because of the excellent annual resolution and are compared with surface temperatures for 1957-85 reconstructed from continental stations and several surrounding island stations. The temperature data were obtained from the National Center for Atmospheric Research and were updated using Jones and Limbert (1987) and the Antarctic Journal of the United States.

With a few exceptions, extreme temperature departures in a single year or season at one station are not necessarily recorded at others. This is particularly true for coastal stations where mesoscale processes may reflect local topography. However, most multi-year trends in both the Faraday and the Amundsen-Scott records (Fig. 6) are reflected in the Siple Station record. Specifically, these are the gradual warming throughout the 1960 s, the persistent warmth from 1970 to 1975 , and the onset of cooling around 1975. Since 1980, temperatures in the Antarctic Peninsula and the $\delta^{18} \mathrm{O}$ record at Siple Station indicate strong warming while cooling has prevailed at the South Pole.

For a larger-scale perspective, two different analyses of surface temperatures $\left(T_{S}\right)$ for high southern latitudes are compared with the Siple Station $\delta^{18} \mathrm{O}$ history (Fig. 7). Hansen and Lebedeff (1987) combined $\tau_{\mathrm{s}}$ (Fig. 7b) for

Table 4. Average annual fluxes at Siple Station for the last two decades

Average annual flux/change from 20 year average

\begin{tabular}{|c|c|c|c|c|c|c|c|c|c|}
\hline & $1966-85$ & \multicolumn{2}{|c|}{$1966-70$} & \multicolumn{2}{|c|}{$1971-75$} & \multicolumn{2}{|c|}{$1976-80$} & \multicolumn{2}{|c|}{$1981-85$} \\
\hline Accumulation (cm w.e.) & 54.2 & 53.0 & $-2 \%$ & 53.3 & $-2 \%$ & 53.4 & $-1 \%$ & 57.0 & $+5 \%$ \\
\hline $\mathrm{Cl}^{-}\left(\mu \mathrm{g} \mathrm{cm}^{-2}\right.$ year $\left.^{-1}\right)$ & 4.53 & 4.47 & $-1 \%$ & 4.07 & $-10 \%$ & 3.98 & $-12 \%$ & 5.59 & $+23 \%$ \\
\hline $\mathrm{SO}_{4}{ }^{2-}\left(\mu \mathrm{g} \mathrm{cm}^{-2}\right.$ year $\left.^{-1}\right)$ & 2.00 & 2.00 & $0 \%$ & 1.76 & $-12 \%$ & 2.24 & $+12 \%$ & 2.00 & $0 \%$ \\
\hline Excess $\mathrm{SO}_{4}{ }^{2-}\left(\mu \mathrm{g} \mathrm{cm}^{-2}\right.$ year $\left.{ }^{-1}\right)$ & 1.37 & 1.37 & $0 \%$ & 1.15 & $-14 \%$ & 1.61 & $+17 \%$ & 1.35 & $-1 \%$ \\
\hline $\mathrm{NO}_{3}^{-}\left(\mu \mathrm{g} \mathrm{cm}^{-2}\right.$ year $\left.{ }^{-1}\right)$ & 1.52 & 1.65 & $8 \%$ & 1.37 & $-10 \%$ & 1.49 & $-3 \%$ & 1.59 & $+5 \%$ \\
\hline
\end{tabular}




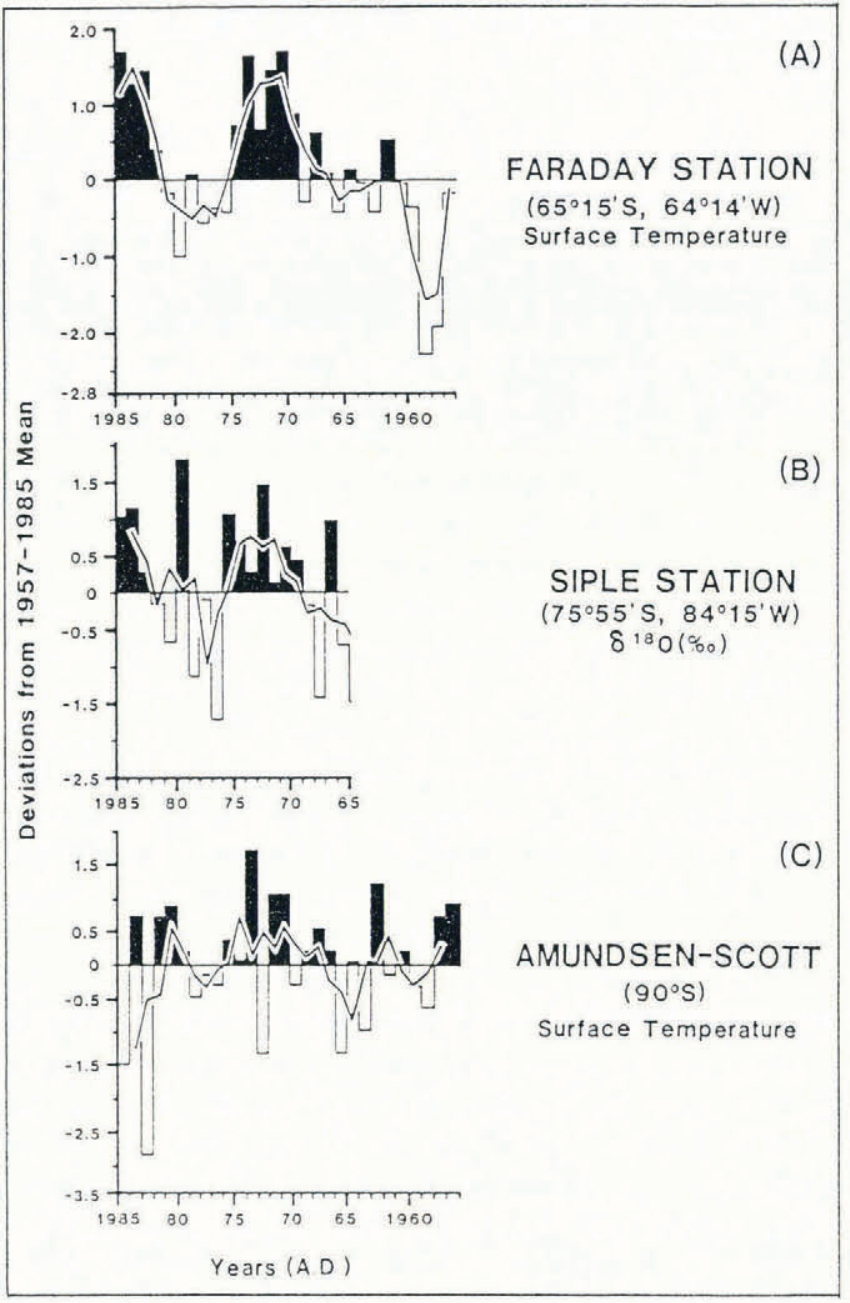

Fig. 6. a. Mean annual temperatures (as departures from 1957-86 mean) for Faraday, Antarctica (Jones and Limbert, 1987); (b) Annual $\delta^{18} O$ record (as departures from 1957-85 mean) from Siple Station, Antarctica; (c) Mean annual temperatures (as departures from 1957-85 mean) for Amundsen-Scott South Pole Station, Antarctica (Jones and Limbert, 1987). These illustrate that extreme annual events at one site may not be recorded elsewhere. However, the broad trends at both Faraday and AmundsenScott are also reflected in the Siple Station $\delta^{18} O$ record.

stations from $64^{\circ}$ to $90^{\circ} \mathrm{S}$ using a method which minimizes the effects of incomplete spatial and temporal coverage and estimates the area over which the temperature change calculated from a given station is meaningful. Raper and others (1984) used monthly surface temperatures from 16 stations $\left(65^{\circ}\right.$ to $\left.90^{\circ} \mathrm{S}\right)$ to produce an areally weighted average for $5^{\circ}$ latitude by $10^{\circ}$ longitude grid cells. The spatial characteristics of the annual and seasonal variations were examined using principal-component analysis (Raper and others, 1984, fig. 6). The time series of the first principal component (PC-1) of annual temperatures (Fig. 7c) explains $35.8 \%$ of the variance. The loadings are positive over all of Antarctica except the sector from $40^{\circ} \mathrm{E}$ to $30^{\circ} \mathrm{W}$, where they are slightly negative. The loadings are strongly positive in the Antarctic Peninsula region, e.g. loadings at Faraday and Siple Station are 0.6 and 0.3 , respectively. The trends in annual $\delta^{18} \mathrm{O}$ at Siple Station and $T_{\mathrm{s}}$ at Faraday (Fig. 6) are consistent with the positive loadings. Amundsen-Scott lies just to the positive side of the 0.0 contour, suggesting little trend in $T_{\mathrm{s}}$ which is evident in Figure 6 . These analyses suggest that South Pole Station may lie near the convergence of two dominant climatic regimes and, thus, may not offer a dependable and/or consistent representation of either regime over longer time-scales. However, its location in a climatically sensitive area could make the South Pole an excellent site for examination of major large-scale atmospheric circulation changes.

The most prominent feature in all the records is the persistent warmth from 1970 to 1975 (Figs 6 and 7) noted by Swanson and Trenberth (1981) and Limbert (1984). Schwerdtfeger (1976) reported a "remarkable" and statistically significant change in the Antarctic Peninsula temperature field in 1970 . The relationship between temperatures at the Argentine Islands $\left(65.13^{\circ} \mathrm{S}\right)$ and Orcadas $\left(60.7^{\circ} \mathrm{S}\right)$, in which the mean annual temperatures at the former were consistently lower for the previous 14 years (1957-70), reversed in 1970. An analysis of the sea-level pressure field (Schwerdtfeger, 1976) suggested an increase in the frequency and strength of winds from the northwest advecting warmer maritime air from the open

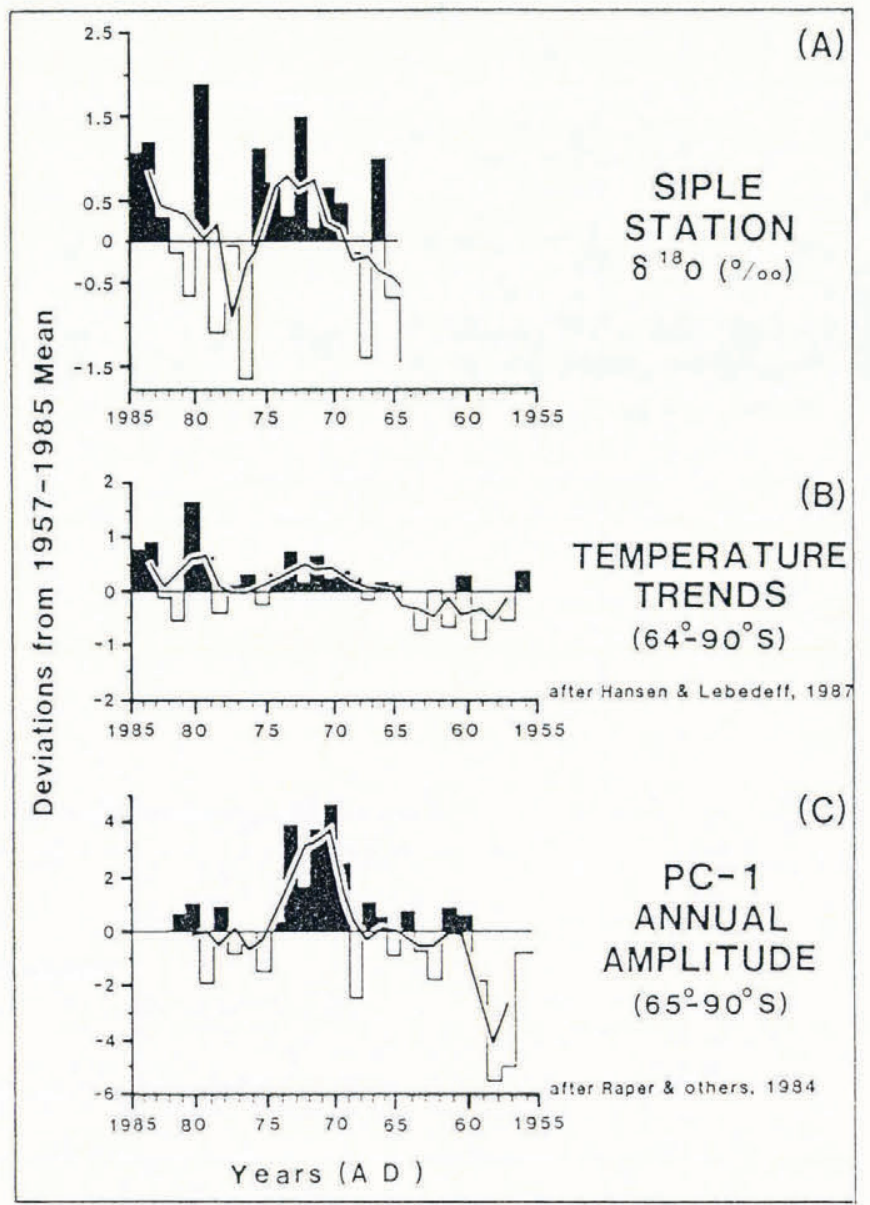

Fig. 7. The Siple Station annual $\delta^{18} \mathrm{O}$ record (departures from 1957-85 mean) is compared with temperature trends (departures from 1957-87 mean) for the $64^{\circ}$ to $90^{\circ} \mathrm{S}$ zone (Hansen and Lebedeff, 1987) and with the 65-90 S. annual temperature departure (from the 1957-82 mean) of the first principal component for areally weighted Antarctica temperature data (Raper and others, 1984). The Siple Station record reflects the same broad trends, although differences exist from year to year. Most prominent are the warming trend in the 1960s and the persistent warmth from 1970 to 1975, followed by cooling later in the decade and warming in the 1980s. 
water of the southeastern Pacific Ocean to the west and northwest side of the Antarctic Peninsula. The recent work by Raper and others (1984) and Hansen and Lebedeff (1987) indicates that the change in the early 1970s affected an area larger than the western coast of the Antarctic Peninsula. The $\delta^{18} \mathrm{O}$ record from Siple Station documents this large-scale event.

The Siple Station $\delta^{18} \mathrm{O}$ record reflects the principal features of both large-scale temperature trends for $64^{\circ}$ to $90^{\circ} \mathrm{S}$ (Fig. 6) and Faraday (with the exception of the extreme value in 1980). As noted earlier, an individual station or recording site experiences short-term, localized events which may not be spatially representative over long distances. However, the data presented in Figure 7 illustrate that the broad trends in the Siple Station $\delta^{18} \mathrm{O}$ record are consistent with the areally averaged Antarctic temperature trends from 1966 to 1985 and reflect even more strongly trends in the Antarctic Peninsula region.

The $\delta^{18} \mathrm{O}$ record from Siple Station can be compared with several other annually resolved $\delta^{18} \mathrm{O}$ and deuterium $(\delta \mathrm{D})$ histories. A 130 year $\delta \mathrm{D}$ record is available from Dalinger Dome (core D-81) on James Ross Island near the tip of the Antarctic Peninsula (Aristarian and others, 1986). The 1970-75 warm event is recorded by $\delta \mathrm{D}$ in the same manner as the Siple Station $\delta^{18} \mathrm{O}$ record, that is, by an overall trend of enrichment and reduced winter depletion. The latter probably reflects the shorter duration of winter and increasing warmth of each season during this time (Limbert, 1984). The James Ross Island record is the first and longest ice-core reconstruction for the Antarctic Peninsula region and corresponds fairly well with the Orcadas record extending back to $\mathrm{AD} 1903$. When the longer record is available from Siple Station, these two records should reveal whether multi-year temperature trends near the tip and base of the Antarctic Peninsula are synchronous.

A similar comparison can be made with the $\delta^{18} \mathrm{O}$ histories from Dolleman Island $\left(70^{\circ} 35.2^{\prime} \mathrm{S}, 60^{\circ} 55.5^{\prime} \mathrm{W}\right)$ and Gomez Nunatak $\left(74^{\circ} 01^{\prime} \mathrm{S}, 70^{\circ} 38^{\prime} \mathrm{W}\right)$ on the Palmer Land plateau (Peel and others, 1988, fig. 2). Both cores exhibit an enrichment trend from 1970 to 1975 followed by increased depletion around 1975 or 1976. A core drilled in 1975 on Dolleman Island makes it possible to examine the 1970-75 event before substantial post-depositional modification (see dotted line in Peel and others, 1988, fig. 2 ). Again, the enrichment trend in the early 1970s is evident. The integration of these $\delta^{18} \mathrm{O}$ records, ranging along the length of the Antarctic Peninsula with the Siple Station record near the base, should provide a regional paleoclimatic record which is currently lacking.

\section{CONCLUSIONS}

Very distinct and well-preserved seasonal signals in $\delta^{18} \mathrm{O}$ and sulfate provide a means for confidently dating a deeper $(302 \mathrm{~m})$ core which should provide a 550 year paleoenvironmental history. The $\delta^{18} \mathrm{O}$ record is remarkably reproducible among four shallow cores and reflects reasonably well the principal features of two different Antarctic composite temperature trends (Fig. 6). The Siple Station $\delta^{18} \mathrm{O}$ record strongly reflects temperature trends at Faraday and is consistent with other isotopic records in the Antarctic Peninsula region.

The high accumulation $\left(0.56 \mathrm{~m} \mathrm{a}^{-1}\right.$ w.e. $)$ leads to extremely low particulate concentrations. Coupled with the potentially excellent time-scale, the Siple Station dust record should provide a well-dated chronicle of major atmospheric turbidity events, such as sporadic or persistent periods of desertification, volcanic activity or increased entrainment of terrestrial material. Sulfate is primarily of non-sea-salt origin and seasonality is a function of available solar radiation which controls sulfate production. The annual sulfate flux exhibits large variability from 1966 to 1985 and may provide a tool for reconstructing Southern Hemisphere volcanic history. The predominant source of chloride at Siple Station is sea-salt aerosol, although it does not appear to be strongly influenced by conditions in the Weddell Sea sector. Nitrate concentrations agree with the levels found by other researchers in the Antarctic Peninsula region; however, a distinct annual concentration variation in nitrate is not found. Nitrate flux is higher during 1976-85 than that during 1971-75. The former encompassed that period when the Antarctic stratospheric ozone was found to be decreasing, but no direct link has been established. The longer chemical records forthcoming from the $302 \mathrm{~m}$ core should provide a valuable history of paleoenvironmental changes in the high southern latitude atmosphere.

Ultimately, the anticipated longer record must be integrated with other recent peleoclimatic histories including those from the Quelccaya ice cap, Peru (Thompson and others, 1984, 1986), James Ross Island, Dolleman Island and Gomez Nunatak in the Antarctic Peninsula. This will provide a valuable history for the southern middle to high latitudes where records are scarce.

\section{ACKNOWLEDGEMENTS}

We thank K. Mountain, for his participation in the field program, and the Polar Ice Coring Office of Lincoln, Nebraska, for conducting the drilling. We gratefully acknowledge the support services of the ITT-ANS contractor and especially L. DeGalen and B. Borden who oversaw the successful return of the ice core to The Ohio State University. We thank K. Doddroe for typing and R. Tope, S. Smith and T. Temple for illustrations. D. Lape and K. Najmulski designed and fabricated the firn sub-coring device. L. Klein and M. Davis conducted the particulate analyses. Their contribution to this work is gratefully acknowledged. This project was supported by U.S. National Science Foundation grant DPP-8410328 to The Ohio State University, and the oxygen-isotope analyses were supported by U.S. National Science Foundation grant DPP-8400574 to the University of Washington. This is contribution 674 of the Byrd Polar Research Center.

\section{REFERENGES}

Arbogast, J. K. 1987. Chromatographic behavior of anions and the first row transition metal ions. (Dissertation, Ohio State University.)

Aristarain, A.J., R.J. Delmas and M. Briat. 1982. Snow 
chemistry on James Ross Island (Antarctic Peninsula). 7. Geophys. Res., 87(C13), 11,004-11,012.

Aristarain, A. J., J. Jouzel and M. Pourchet. 1986. Past Antarctic Peninsula climate (1850-1980) deduced from an ice core isotope record. Climatic Change, 8(1), 69-89.

Delmas, R. J., J. M. Barnola and M. Legrand. 1982. Gasderived aerosol in central Antarctic snow and ice: the case of sulphuric and nitric acids. Ann. Glaciol., 3, 71-76.

Delmas, R.J., M. Legrand, A.J. Aristarain and F. Zanolini. 1985. Volcanic deposits in Antarctic snow and ice. 7. Geophys. Res., 90(D7), 12,901-12,920.

Farman, J. C., B. G. Gardiner and J. D. Shanklin. 1985. Large losses of total ozone in Antarctica reveal seasonal $\mathrm{ClO}_{\mathrm{x}} / \mathrm{NO}_{\mathrm{x}}$ interaction. Nature, 315(6016), 207-210.

Friedli, H., H. Lotscher, H. Oeschger, U. Siegenthaler and B. Stauffer. 1986. Ice core record of the ${ }^{13} \mathrm{C} /{ }^{12} \mathrm{C}$ ratio of atmospheric $\mathrm{CO}_{2}$ in the past two centuries. Nature, 324(6094), 237-238.

Hansen, J. and S. Lebedeff. 1987. Global trends of measured surface air temperature. 7. Geophys. Res., 92(D11), 13,345-13,372.

Heath, D. F. 1988. Non-seasonal changes in total column ozone from satellite observations, 1970-86. Nature, 332(6161), 219-227.

Herron, M. M. 1982. Impurity sources of $\mathrm{F}^{-}, \mathrm{Cl}^{-}, \mathrm{NO}_{3}^{-}$ and $\mathrm{SO}_{4}{ }^{-2}$ in Greenland and Antarctic precipitation. $\mathcal{F}$. Geophys. Res., 87(C4), 3052-3060.

Jones, P. D. and D.W.S. Limbert. 1987. A data bank of Antarctic surface temperature and pressure data. Springfield, VA, National Technical Information Service. (Department of Energy Report DOE/ER/60397-H2.)

Legrand, M. R. and R.J. Delmas. 1984. The ionic balance of Antarctic snow: a 10-year detailed record. Atmos. Environ., 18(9), 1867-1874.

Legrand, M.R. and R.J. Delmas. 1985. Spatial and temporal variations of snow chemistry in Terre Adélie (East Antarctica). Ann. Glaciol., 7, 20-25.

Legrand, M. R., M. De Angelis and R.J. Delmas. 1984. Ionic chromatographic determination of major ions at ultratrace levels in Antarctic snow and ice. Anal. Chim. Acta, 156, 181-192.

Limbert, D. W. S. 1984. West Antarctic temperatures, regional difference and the nominal length of summer and winter seasons. Environment of West Antarctica: Potential $\mathrm{CO}_{2}$-Induced Changes Workshop report, 5-7 July, 1983. Madison, Wisconsin. Washington, DC, National Academy Press.

McKeen, S. A., S. C. Liu and C.S. Kiang. 1984. On the chemistry of stratospheric $\mathrm{SO}_{2}$ from volcanic eruptions. 7. Geophys. Res., 89(D3), 4873-4881.

Mosley-Thompson, E., E. R. Mountain and J. F. Paskievitch. 1986. Paleoclimatic ice core program at Siple Station. Antarct. F. U.S., 21(5), 115-117.

Mulvaney, R. and D. A. Peel. 1988. Anions and cations in ice cores from Dolleman Island and the Palmer Land plateau, Antarctic Peninsula. Ann. Glaciol., 10, 121-125.

National Research Council. 1986. Global change in the geosphere- biosphere. Initial priorities for an IGBP. Washington, DC, National Academy Press.

National Research Council. 1988. Toward an understanding of global change: initial priorities for U.S. contribution to the International Geosphere-Biosphere Program. Washington,
DC, National Academy Press.

Neftel, A., E. Moor, H. Oeschger and B. Stauffer. 1985. Evidence from polar ice cores for the increase in atmospheric $\mathrm{CO}_{2}$ in the past two centuries. Nature, 315(6014), 45- 47.

Peel, D. A., R. Mulvaney and B. M. Davison. 1988. Stable-isotope/air-temperature relationships in ice cores from Dolleman Island and the Palmer Land plateau, Antarctic Peninsula. Ann. Glaciol., 10, 130-136.

Raper, S. C. B., T. M. L. Wigley, P. R. Mayes, P. D. Jones and M.J. Salinger. 1984. Variations in surface air temperatures. Part 3. The Antarctic, 1957-82. Mon. Weather Rev., 112, 1342-1353.

Saigne, C., S. Kirchner and M. Legrand. 1987. Ionchromatographic measurements of ammonium, fluoride, acetate, formate, and metasulphonate ions at very low levels in Antarctic ice. Anal. Chim. Acta, 203(1), 11-21.

Schwander, J. 1984. Lufteinschluss im Eis von Grønland und der Antarktis. Messung der elektrischen Leitfähigkeit von Eisproben für klimatologische Anwendungen. (Ph.D. dissertation, Universität Bern.)

Schwerdtfeger, W. 1976. Changes of temperature field and ice conditions in the area of the Antarctic Peninsula. Mon. Weather Rev., 104(11), 1441-1443.

Schwerdtfeger, W. and L. R. Amaturo. 1979. Wind and weather around the Antarctic Peninsula. Madison, WI, University of Wisconsin. Department of Meteorology.

Stauffer, B. and H. Oeschger. 1985. Gaseous components in the atmosphere and the historic record revealed in ice cores. Ann. Glaciol., 7, 54-59.

Swanson, G. S. and K.E. Trenberth. 1981. Trends in the Southern Hemisphere troposphere. Mon. Weather Rev., 109, 1890-1897.

Thompson, L. G. 1977. Microparticles, ice sheets and climate. Ohio State Univ. Inst. Polar Stud. Rep. 64.

Thompson, L. G. and E. Mosley-Thompson. 1982. Spatial distribution of microparticles within Antarctic snowfall. Ann. Glaciol., 3, 300-306.

Thompson, L.G., E. Mosley-Thompson and B.M. Morales Arnao. 1984. El Niño - southern oscillation events recorded in the stratigraphy of the tropical Quelccaya Ice Cap, Peru. Science, 226(4670), 50-53.

Thompson, L. G., E. Mosley-Thompson, W. Dansgaard and P. M. Grootes. 1986. The Little Ice Age as recorded in the stratigraphy of the tropical Quelccaya Ice Cap. Science, 234(4774), 361-364.

Wagenbach, D., U. Gorlach, K. Moser and K. O. Münnich. 1988. Coastal Antarctic aerosol: the seasonal pattern of its chemical composition and radionuclide content. Tellus, 40B, 426-436.

Zanolini, F., R.J. Delmas and M. Legrand. 1985. Sulphuric and nitric acid concentrations and spikes along a $200 \mathrm{~m}$ deep ice core at D 57 (Terre Adélie, Antarctica). Ann. Glaciol., 7, 70-75.

Zeller, E.J., G. A. Dreschoff and C.M. Laird. 1986. Nitrate flux on the Ross Ice Shelf, Antarctica, and its relation to solar cosmic rays. Geophys. Res. Lett., 13(12), $1264-1267$.

The accuracy of references in the text and in this list is the responsibility of the authors, to whom queries should be addressed. 